\title{
PENGARUH KEPATUHAN DAN PENGETAHUAN RAMBU KESELAMATAN TERHADAP KESELAMATAN KERJA DI LABORATORIUM PT GEOSERVICES BALIKPAPAN
}

\author{
Hardiyono ${ }^{1}$, Sri Purwanti², Komeyni Rusba ${ }^{3}$, Eko Agus Novianto ${ }^{4}$ \\ Program Studi Keselamatan dan Kesehatan Kerja Fakultas Vokasi Universitas Balikpapan \\ Email: hardiyono@uniba-bpn.ac.id
}

\begin{abstract}
ABSTRAK
Analisis tentang tingkat kepatuhan dan pengetahuan karyawan dengan terpasangnya rambu-rambu keselamatan, apakah berpengaruh dalam tingkat kesadaran pekerja terhadap bahaya akan keselamatan kerja di PT Geoservices Balikpapan. Metode yang digunakan dalam penelitian ini adalah metode dengan pendekatan kuantitatif melalui kuesioner dan kemudian di lihat dari pendekatan kualitatif melalui observasi dan wawancara yang bertujuan untuk mendapatkan gambaran penuh terhadap pengaruh kepatuhan dan pengetahuan terhadap keselamatan kerja. Terdapat hasil analisa persamaaan linier berganda yaitu: $\mathrm{Y}=2.782+1,000 \times 1+1,000 \times 2$ yang mana jika hubungan koefisien konstanta $a=2,782$ mengidikasikan bahwa jika kepatuhan dan pengetahuan tetap/tidak mengalami penambahan atau pengurangan, maka keselamatan kerja sebesar nilai konstanta yaitu 2,782. Setiap kenaikan satu satuan kepatuhan pekerja terhadap rambu-rambu keselamatan maka keselamatan kerja akan naik sebesar 1,000. Setiap kenaikan pengetahuan pekerja terhadap rambu-rambu keselamatan sebesar satu satuan maka keselamatan kerja akan naik sebesar 1,000 .
\end{abstract}

Kata Kunci: keselamatan kerja, kepatuhan pekerja, pengetahuan pekerja.

\begin{abstract}
Analysis of the level of compliance and knowledge of employees with the protection of safety signs, whether it affects the level of awareness of workers on the danger of working safety at PT Geoservices Balikpapan. The method used in this study is a method with a quantitative approach through questionnaires and then in view of a qualitative approach through observation and interviews aiming to get a full picture of the influence Compliance and knowledge of occupational safety. There is a result of a double linear association which is: $Y=2,782+1,000 X 1+1,000 X 2$ which if the relationship of constant coefficient $a=2,782$ indicate that if compliance and knowledge remain/do not experience addition or subtraction, then occupational safety constant value of 2.782. Each increment of one unit of safety signs compliance then occupational safety will increase by 1,000. Each increase in knowledge of safety signs of one unit and then safety will increase by 1,000. In addition, there is a percentage result of the test coefficient of determination which is used to determine how large the percentage of contributions of independent variable influence simultaneously on its dependencies variable. This is shown with the result of a coefficient of determination in the level of knowledge on occupational safety shows the value of 0,643 so that the contribution of the knowledge independent variable of $64,3 \%$ to the dependent variable of occupational safety While the rest is 35,7\% in influence other factors.
\end{abstract}

Keyword: Occupational safety, worker compliance, worker knowledge 


\section{PENDAHULUAN}

Perkembangan industri di Indonesia semakin pesat, baik itu industri rumah tangga, UKM maupun industri kelas atas. Dimana industri ini tentunya bergerak dalam bidang yang berbeda-beda sehingga bentuk pengerjaan dan potensi bahaya yang adapun juga berbeda-beda.

Melihat kondisi tersebut maka dalam dunia kerja dengan dunia pendidikan tentunya mempunyai perbedaan yang signifikan. Salah satu konsekuensi dari perkembangan industri yang pesat dan persaingan yang ketat antar perusahaan di Indonesia saat ini adalah tantangan proses produksi kerja dalam perusahaan supaya terus menerus berproduksi selama hampir 24 jam.

PT Geoservice sebagai perusahaan dalam jasa analisa batu bara maka tidak bisa di pungkiri bahwa peralatan laboratorium penguji tidak terlepas dari risiko bahaya terhadap peralatan kerja elektronik dan senyawa larutan bahan kimia yg bersifat sebagai pereaksi terhadap sampel contoh. Dan dalam pengerjaan pengujian di butuhkan kewaspadaan dalam pengoperasian alat-alat laboratorium menurut Standar Operational Prosedur (SOP) yang telah terakreditasi. Proses pekerjaan pengujian contoh analisa batu bara di mulai dari dua tahapan area kerja yaitu proses pertama di Area Kerja Preparasi dan kemudian tahap kedua di Area Laboratorium. Tujuan Penelitian ini adalah untuk mendapatkan hasil analisis tentang tingkat kepatuhan dan pengetahuan karyawan dengan terpasangnya rambu-rambu keselamatan apakah berpengaruh dalam tingkat kesadaran pekerja terhadap bahaya akan keselamatan kerja di PT Geoservices Balikpapan.

\section{METODE PENELITIAN}

Penelitian ini menggunakan pendekatan kuantitatif melalui kuesioner kemudian di lihat dari pendekatan kualitatif melaui observasi dan wawancara yang bertujuan untuk mendapatkan gambaran penuh pengaruh kepatuhan dan pengetahuan terhadap keselamatan kerja. Dalam penelitian ini variabel yang di ukur yaitu:

a. Variabel Bebas (X)

Variabel Bebas adalah faktor stimulus/input yang di pilih peneliti untuk melihat pengaruh-pengaruh terhadap gejala yang di amati. Variabel bebas dalam penelitian ini adalah tingkat kepatuhan pekerja (X1) terhadap rambu keselamatan dalam bekerja dan tingkat pengetahuan pekerja (X2) terhadap rambu keselamatan dalam bekerja.

b. Variabel Terikat (Y)

Variabel teriakat yaitu faktor yang di amati dan di ukur untuk mengetahui efekefek variabel bebas (Nasution, 2009;56). 
Variabel terikat dalam penelitian ini adalah Keselamatan kerja di laboratorium (Y).

Jika di gambarkan hubungan antara variabel penelitiannya adalah sebagai berikut:

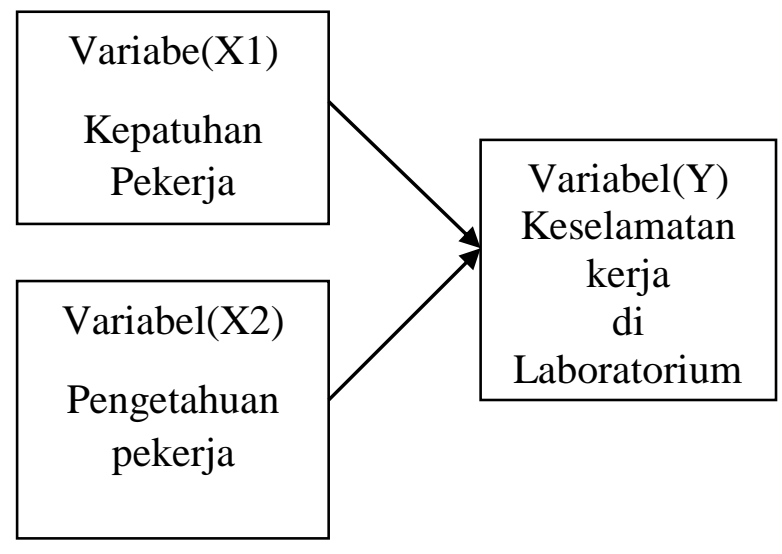

Gambar 1. Hubungan Antara Variabel

Kemudian untuk menghitung hasil yang di dapatkan dengan menggunakan Uji

Instriument yang meliputi:

1. Uji Validitas Instrumen

Validitas Instrumen adalah keteepatan dari suatu instrumen atau alat pengukur terhadap konsep yang akan di ukur, sehingga suatu instrumen akan di katakan memiliki taraf validitas yang baik jika betul-betul mengukur apa yang hendak di ukur. Untuk menguji validitas angket digunakan rumus koefisien reprodubilitas dan koefisien skalabilitas. Adapun koefisien reprodubilitas dapat di ukur dengan mengguanakan rumus: Rumus Koefisien Reprodusibilitas:

$$
\mathrm{Kr}=\mathbf{1 - ( e / n )}
$$

\section{Keterangan:}

e $=$ jumlah kesalahan/nilai error $\mathrm{n}=$ jumlah pernyataan dikali jumlah

responden.

Syarat penerimaan nilai koefisien reprodusibiltas yaitu apabila koefisien reprodusibiltas memiliki nilai $>0,90$ (Sugiono, 2007). Sedangkan rumus Koefisien Skalabilitas yaitu:

Rumus Koefisien Skalabilitas

$\mathrm{Ks}=\mathbf{1 -}(\mathbf{e} / \mathbf{x})$

Dimana:

$\mathrm{e}=$ jumlah kesalahan/nilai error

$\mathrm{x}=0,5(\{$ jumlah pernyataan dikali jumlah responden \} - jumlah jawaban "ya")

Syarat penerimaan nilai koefisien skalabilitas yaitu apabila koefisien skalabilitas memiliki nilai > 0, 60 (Sugiono, 2007).

2. Uji Regresi Linier Berganda

Uji regresi linier berganda merupakan analisis yang dapat digunakan untuk menghitung besarnya pengaruh antara variabel bebas yaitu kepatuhan pekerja (X1) dan pengetahuan pekerja (X2) terhadap variabel terikat yaitu keselamatan kerja di laboratorium (Y). Spesifikasi dari model regresi linier berganda sebagai berikut.

$Y=a+b 1 X 1+b 2 X 2$

Dimana:

$\mathrm{Y} \quad=$ Keselamatan Kerja

A $\quad$ Konstanta

$\mathrm{b} 1+\mathrm{b} 2=$ Koefisien garis regresi

$\mathrm{X} 1=$ Kepatuhan

$\mathrm{X} 2=$ Pengetahuan 
Model ini di gunakan untuk mengetahui seberapa besar pengaruh kepatuhan pekerja dan pengetahuan pekerja rambu keselamatan terhadap keselamatan kerja di PT Geoservices Balikpapan. Perhitungan regresi linier berganda diperoleh parameterparameter koefisien, baik yang bertanda positif maupun bertanda negatif. Hasil yang diperoleh akan dibandingkan dengan teori yang ada, apakah sesuai atau tidak. Apabila sesuai, maka akan dilanjutkan dengan pengujian melalui tahap:

\section{a. Uji Signifikan Simultan (Uji F)}

Untuk membuktikan kebenaran hipotesis pertama di gunakan uji $\mathrm{F}$, dalam penelitian ini bertujuan untuk mengetahui tingkat signifikansi pengaruh variabel-variabel bebas secara bersama-sama (simultan) terhadap variabel terikat.

\section{b. Uji Signifikasi Pengaruh Parsial (Uji T)}

Kebenaran hipotesis kedua di buktikan dengan menggunakan uji $\mathrm{T}$ yaitu menguji kebenaran koefisien regresi parsial.

\section{HASIL DAN PEMBAHASAN}

Persamaan regresi linier berganda dipergunakan untuk melihat bentuk hubungan yang terjadi antara variabel bebas dengan variabel terikat. Model ini di gunakan untuk mengetahui seberapa besar pengaruh kepatuhan dan pengetahuan rambu keselamatan terhadap keselamatan kerja di PT Geoservices Balikpapan.
$\mathrm{Y}=2,782+1,000 \mathrm{X} 1+1,000 \mathrm{X} 2$

Dari persamaan tersebut diinterpretasikan sebagai berikut:

1. Keselamatan kerja dapat mengalami peningkatan sebesar 1,000 satuan untuk setiap tambahan satu satuan X1 (kepatuhan pekerja), jadi apabila kepatuhan meningkat 1 satuan, maka keselamatan kerja juga akan meningkat sebesar 1,000 .

2. Keselamatan kerja dapat mengalami peningkatan sebesar 1,000 satuan untuk setiap tambahan satu satuan X2 (pengetahuan pekerja), jadi apabila pengetahuan meningkatan 1 satuan, maka keselamatan kerja juga akan mengalami peningkatan sebesar 1,000 .

Berdasarkan hasil tersebut, maka dapat diketahui bahwa besarnya kontribusi variabel bebas terhadap variabel terikat, yaitu kepatuhan pekerja sebesar 1,000. Pengetahuan pekerja sebesar 1,000. Dapat disimpulkan bahwa kepatuhan dan pengetahuan pekerja pada rambu keselamatan kerja berpengaruh positif terhadap keselamatan kerja. Jadi jika kepatuhan pekerja dan pengetahuan pekerja terhadap rambu keselamatan kerja meningkat maka akan diikuti peningkatan terhadap keselamatan kerja. 
Berdasarkan hasil regersi linear berganda maka perlu dilakukan uji hipotesis oleh peneliti yaitu:

\section{Hipotesis I (F test / Simultan)}

Hasil analisis diperoleh nilai signifikansi $\mathrm{F}(0,000)<\alpha=0.05$ maka model analisis regresinya adalah signifikan. yang berarti bahwa $\mathrm{H} 0$ ditolak dan $\mathrm{H} 1$ diterima sehingga dapat ditarik kesimpulan bahwa secara signifikan variabel Y (keselamatan kerja di laboratorium) dapat dipengaruhi oleh variabel kepatuhan pekerja (X1) dan pengetahuan pekerja (X2).

\section{Hipotesis II (t-test/parsial)}

Berdasarkan hasil analisis uji t diperoleh hasil sebagai berikut:

a. Hasil dari t-test antara X1 (kepatuhan pekerja) dengan Y (keselamatan kerja di laboratorium) menunjukkan bahwa nilai signifikasi $\mathrm{t}(0,000)<\alpha=0.05$ maka $\mathrm{H} 0$ di tolak dan $\mathrm{H} 1$ diterima sehingga pengaruh X1 (kepatuhan pekerja) terhadap keselamatan kerja adalah signifikan. Sehingga dapat ditarik kesimpulan bahwa secara signifikan kepatuhan pekerja terhadap rambu keselamatan akan dipengaruhi oleh keselamatan kerja, kalau kepatuhan meningkat maka keselamatan kerja juga akan mengalami peningkatan pula.

b. Hasil dari t-test antara X2 (pengetahuan pekerja) dengan Y (keselamatan kerja di laboratorium) memperlihatkan bahwa nilai signifikasi $\mathrm{t}(0,000)<\alpha=0.05$ jadi dapat diketahui pengaruh X2 (pengetahuan pekerja) terhadap keselamatan kerja adalah signifikan sehingga dapat ditarik kesimpulan bahwa secara signifikan keselamatan kerja dapat dipengaruhi oleh pengetahuan pekerja atau dengan meningkatkan pengetahuan pekerja maka keselamatan kerja juga akan mengalami peningkatan.

\section{KESIMPULAN}

Dari data yang telah diperoleh, maka dapat diambil beberapa kesimpulan diantaranya:

1. Dari hasil analisis persamaan linier berganda didapat hasil:

$\mathrm{Y}=2,782+1,000 \times 1+1,000 \times 2$

Hubungan koefisien konstanta $a=2,782$ mengidentifikasi bahwa jika kepatuhan pekerja dan pengetahuan pekerja tetap/tidak mengalami penambahan atau pengurangan, maka keselamatan kerja sebesar nilai konstanta yaitu 2,782. Jika nilai koefisien terhadap kepatuhan pekerja (X1) terhadap rambu-rambu keselamatan sebesar 1,000 .

Hal ini mengandung arti bahwa setiap kenaikan kepatuhan pekerja terhadap rambu-rambu keselamatan sebesar satu satuan maka keselamatan kerja (Y) akan naik sebesar 1,000 dengan asumsi bahwa variabel bebas yang lain dari model 
regresi tetap. Sedangkan jika nilai koefisien terhadap pengetahuan pekerja terhadap rambu-rambu keselamatan untuk (X2) sebesar 1,000.

Hal ini mengandung arti bahwa setiap kenaikan pengetahuan pekerja terhadap rambu-rambu keselamatan sebesar satu satuan maka keselamatan kerja (Y) akan naik sebesar 1,000 dengan asumsi bahwa variabel bebas yang lain dari model regresi tetap.

2. Pengaruh secara parsial untuk kepatuhan pekerja (X1) terhadap rambu keselamatan kerja dan pengetahuan pekerja (X2) terhadap rambu keselamatan kerja terhadap keselamatan kerja dengan melakukan pengujian t-test.

Berdasarkan perhitungan yang telah dilakukan peneliti dapat dilihat bahwa dari kedua variabel bebas tersebut yang paling dominan pengaruhnya terhadap prestasi kerja adalah pengetahuan pekerja terhadap rambu keselamatan kerja karena memiliki nilai koefisien t hitung paling besar.

3. Pengaruh secara bersama-sama (simultan) terhadap keselamatan kerja dengan melakukan pengujian $F$-test. Hasil analisis regresi berganda menjelaskan bahwa Ho ditolak dan Ha diterima, dari sini dapat diketahui variabel bebas mempunyai pengaruh yang signifikan secara simultan terhadap keselamatan kerja.

\section{DAFTAR PUSTAKA}

Abdurrahman, S, 2013, Modul Kesehatan dan Keselamatan Kerja (pp. 26). Rosslyn: National Electrical Manufactures Association. Electrical Manufactures Association (NEMA).

Alijoyo, Antonius, 2005, Enterprise Risk Management, Pendekatan Praktis. Ray Indonesia. Australia Standars/New Zaeland. 2004. Risk Management 4360. Standard

ANSI Standard, 2007, ANSI Z535.4-2007 for Product Safety Sign and Labels.

ANSI Standard, 2011, ANSI Z535.3-2011 Criteria for Safety Symbol. National

B. Miles, Matthew \& Huberman, A. Michael, 1992, Analisis Data Kualitatif. Terjemahan Tjetjep Rohendi Rohidi, UI Press, Jakarta.

Cahyani, P, 2009, Pemetaan Sistem Organisasi Sebagai Refleksi Budaya Keselamatan Kerja (Safety Culture) Industri Manufaktur Indonesia. Institut Teknologi Bandung, Bandung.

Evianti, Anggun Lestari, 2014. Kesesuaian Keberadaan Safety Sign Berdasarkan Identifikasi Bahaya Di PT Dirgantara Indonesia, UIN, Jakarta.

Herdiansyah, Haris, 2011, Metodologi Penelitian Kulitatif. Salemba Humanika, Jakarta.

Juliana, Anda Ivana, 2008, Implementasi Metode Hazops dalam Proses Identifikasi Bahaya dan Analisa Risiko Pada Feedwater System di Unit Pembangkitan Paiton PT. PJB. Surabaya: Politeknik Perkapalan Negeri Surabaya. 
Ramli, S, 2010, Manajemen Risiko Dalam Perspektif K3 OHS Risk Management. Dian Rakyat. Jakarta.

Ramli, S. 2010b. Sistem Manajemen Keselamatan dan Kesehatan Kerja OHSAS 18001 (Vol. 01), Dian Rakyat, Jakarta.

Tarwaka. 2008. Manajemen dan Implementasi K3 di Tempat Kerja. Harapan Press, Surkarta. 